Original Research Article

\title{
Study of self drug administration among second professional medical students
}

\author{
Asish Kumar Biswas, Gajendra Kumar Singh*, Akash Chandra, \\ Upendra Kumar, Amrendra Narayan Mishra
}

Department of Pharmacology, M.G.M Medical College, Jamshedpur, Jharkhand, India

Received: 03 August 2019

Revised: 17 September 2019

Accepted: 19 September 2019

*Correspondence to:

Dr. Gajendra Kumar Singh,

Email: drgksingh.jsr@ gmail.com

Copyright: (C) the author(s), publisher and licensee Medip Academy. This is an openaccess article distributed under the terms of the Creative Commons Attribution NonCommercial License, which permits unrestricted noncommercial use, distribution, and reproduction in any medium, provided the original work is properly cited.

\begin{abstract}
Background: Self-medication is very common in our day to day life which is an unhealthy and risky practice. Present study was done to determine the knowledge, attitude and practice among second professional medical students.

Methods: A questionnaire related to self-medication with consent was prepared and distributed among the students of second professional. Data was collected and analysed the results expressed as counts and percentages.

Results: Total 100 students participated in the study for taking self-medication and was no need to visit the doctor for minor illness. In maximum students, source of information of the drugs used for self-medication pharmacological based and learning process in the college. The source of drug was medical store. Most of the students took self-medication for loose motion and headache followed by cough, cold and fever. Out of total 100 students most of the students took paracetamol tablet as self-medication.

Conclusions: This study showed that second professional medical students after studying pharmacological books they do not use any wrong medicine as selfmedication. High level of awareness of second professional students has minimized self medication.
\end{abstract}

Keywords: Self-medication, Questionnaire, Second professional students

\section{INTRODUCTION}

Self-medication is defined as the use of medication by a patient on his own initiative or on the advice of a Pharmacist or a lay person instead of consulting a medical practitioner (WHO guidelines, 2000). ${ }^{1}$ It has been observed that medical and paramedical students are commonly involved in the practice of self-medication, without complete knowledge about the therapy they are taking. ${ }^{2}$ Non-prescription drugs amongst youth, especially in students are being misused due to exposure to media and advertisements. It has become a serious ailment raising the concern of incorrect diagnosis and drug reaction as well. Being future medical practitioners, selfmedication has a special impact in medical students. Prevalence of self-medication was found to vary in medical students of different countries in earlier studies. ${ }^{3}$ On one hand, students become more and more cautious in practising self-medication, knowing that irrational and inappropriate usage of them might be more harmful than useful, so they, even in situations of minor illnesses prefer taking any medication only after consultation from a qualified practitioner. On the other hand, they may become confident, and in most cases, overconfident, 
regarding their "bookish" knowledge and may start implementing self-care. However, it is also recognized that self-medication must be accompanied by appropriate health information. ${ }^{4}$ Second professional medical students know about drugs while studying Pharmacology. There is a strong possibility of self-medication among $2^{\text {nd }}$ professional medical students. It will be a risky procedure. This work has been designed to evaluate the extent of self-medication among second professional medical students.

\section{METHODS}

An anonymous questionnaire-based study in all the medical students of 2nd year MBBS students [Batch 2017-2018] attending theory classes in the department of Pharmacology in M.G.M Medical college, Jamshedpur of India, was conducted after getting permission from ethics committee of the college. Students of all ages and both sexes were included in the study. The study period is of total three months from 05 March 2019 to 05 June 2019. A brief description of the nature of the study and the procedure of completing the questionnaire was explained to students taking part in the study. Questionnaire was self-developed and pre validated consisting of twelve closed ended questions. The survey was descriptive and data was summarised as counts and percentages. Microsoft word and excel programs were used for analysis of data. A questionnaire related to selfmedication with consent was prepared and distributed among the students of second professional. Data was collected and analysed the results expressed as counts and percentages.

\section{RESULTS}

The Table 1 is showing that 70 students have selfconfidence regarding knowledge about medicines. About 72 students think that it is not compulsory to consult doctor for minor illness. About 86 students have given opinion that there is wastage of time to go doctor's clinic.

Table 1: Reasons given by students in favour of self medication.

\begin{tabular}{|l|l|}
\hline Reasons & No. of students \\
\hline $\begin{array}{l}\text { Confidence regarding knowledge } \\
\text { about medicines }\end{array}$ & 70 \\
\hline $\begin{array}{l}\text { Not compulsory to consult doctor } \\
\text { for minor Ailments }\end{array}$ & 72 \\
\hline Saving of time & 86 \\
\hline
\end{tabular}

The Table 2 is showing the number of students who are suffering from various ailments as- headache, cough and cold, vomiting skin infection etc. and taken medicines for these ailments.
Table 2: Self-medication done by students for various ailments.

\begin{tabular}{|l|l|}
\hline Ailments & No. of students \\
\hline Headache & 70 \\
\hline Cough and cold & 55 \\
\hline Fever & 80 \\
\hline Loose motion & 74 \\
\hline Vomiting & 44 \\
\hline Skin infection & 65 \\
\hline Acidity & 44 \\
\hline
\end{tabular}

The Table 3 is showing the name of various medicines taken by students as self-medication

Table 3: Different medicines used for self-medication in our study.

\begin{tabular}{|ll|}
\hline Medicines & No. of students \\
\hline Tab. paracetamol & 74 \\
\hline Capsule amoxycillin & 54 \\
\hline Tablet metronidazole & 70 \\
\hline Capsule omeprazole & 37 \\
\hline Tablet domperidon & 42 \\
\hline Neosporin ointment & 62 \\
\hline
\end{tabular}

\section{DISCUSSION}

In our study, we found that female students were more interested in taking self-medication as compared to male students; this may be due to the fact that the female students are more hesitant to go to the hospital or outpatient department for minor illness. Similar findings were there in the study done by Thadani. ${ }^{5}$ In our study most of the students have taken tablet Paracetamol for headache. In our survey it is clear that Paracetamol tablet is safest drug among all drugs which are taken by about 74 students as self-medication and it is confirmed by students itself. About 86 students out of 100 have given reason of saving of time in favour of self-medication. In our study it is clear that students have not taken any wrong medicines as self-medication. Self-medication is the utilization of medicines by persons on their own without any proficient medical supervision. In developing countries like India, most episodes are treated by selfmedication due to easy availability of non-prescription drugs. It is more likely to be inappropriate without complete knowledge although it is becoming a routine practice nowadays especially by undergraduate medical students. $^{6}$ The prevalence of self-medication varied amongst different years of students and found increasing from first year to final year and the reason might be the knowledge of medicines in final year students which is comparable with the findings of previously conducted studies. ${ }^{7}$ Self-medication amongst students is a global problem. ${ }^{8}$ Studies in India report a rising incidence. ${ }^{9}$ 


\section{CONCLUSION}

This study showed that second professional medical students after studying pharmacological books they do not use any wrong medicine as self-medication done by second professional medical students are more or less safer groups of drugs for very common ailments. High level of awareness of second Professional students has minimized self-medication. High level of awareness acquired by second professional students restricts the selfmedication covering only few common ailments by very safe drugs. The study gives the message that scientific knowledge and awareness will minimize the selfmedication which is supposed to be a risky and harmful practice.

Funding: No funding sources Conflict of interest: None declared

Ethical approval: The study was approved by the Institutional Ethics Committee

\section{REFERENCES}

1. Porteous T, Bond C, Hannaford P, Sinclair H. How and why are non-prescription analgesics used in Scotland? Fam Pract. 2005;22(1):78-85.

2. Montgomery AJ, Bradley C, Rochfort A, Panagopoulou E. A review of self-medication in physicians and medical students. Occup Med (Lond). 2011;61(7):490-7.

3. Zafar SN, Syed R, Waqar S, Zubairi AJ, Vaqar T, Shaikh M, et al. Self-medication amongst University
Students of Karachi: Prevalence, Knowledge and Attitudes. J Pak Med Assoc. 2008;58(4):214-7.

4. James H, Handu SS, Al Khaja KA, Otoom S, Sequeria RP. Evaluation of the knowledge, attitude, and practice of self- medication among first-year medical students. Med Princ Pract. 2006;15(4):270-5.

5. Thadani S, Salman MT, Ahmad A. Knowledge, Attitude and Practice of Self-medication Among Second Year Undergraduate Medical Students. J Rational Pharmacother Res. 2013;1(3):131-4.

6. Klemenc-Ketis Z, Hladnik Z, Kersnik J. Selfmedication among healthcare and non-healthcare students at University of Ljubljana, Slovenia. Med Princ Pract. 2010;19:395-401.

7. Banerjee I, Bhadury T. Self-medication practice among undergraduate medical students in a tertiary care medical college, West Bengal. J Postgrad Med. 2012;58:127-31.

8. Sawalha AF. Assessment of self-medication practice among university students in Palestine: Therapeutic and Toxicity implications. The Islamic Univ J. 2007;15:67-82.

9. Sontakke SD, Bajait CS, Pimpalkhute SA, Jaiswal KM, Jaiswal SR. Comparative study of evaluation of self - Medication practices in first and third year medical students. Int J Biol Med Res. 2011;2:561-4.

Cite this article as: Biswas AK, Singh GK, Chandra A, Kumar U, Mishra AN. Study of self drug administration among second professional medical students. Int J Basic Clin Pharmacol 2019;8:2294-6. 